\title{
TRH Stimulation When Basal TSH is Within the Normal Range: Is There "Sub-Biochemical” Hypothyroidism?
}

\author{
Suhail A.R. Doi, PhD, FRCP; Daisy Issac, MSc; Sheikha Abalkhail, MRCP; \\ Marwa M. Al-Qudhaiby, MBBS; Mohamad F. Hafez, MBBS; and Kamal A. S. Al-Shoumer, PhD, FRCP
}

Keywords:

Diagnosis,

Sub-clinical hypothyroidism,

TRH test
Reprint Requests:

Suhail A.R. Doi, PhD, FRCP

Department of Medicine (Endocrinology)

Mubarak Al-Kabeer Teaching Hospital and

Kuwait University

Kuwait

Tel.: $+965688-6335$

Fax: +44 (709) 237-7990

Email: sardoi@gmx.net
Received: February 12, 2007

Revised: May I, 2007

Accepted: May 4, 2007

doi: $10.3121 / \mathrm{cmr} .2007 .756$
$\mathrm{T}$ he standard thyrotropin releasing hormone (TRH) test $(200 \mu \mathrm{g})$ with synthetic TRH is no longer used commonly for the detection of primary hypothyroidism or hyperthyroidism. The reason has been that this test has been replaced by the development of more sensitive thyroid-stimulating hormone (TSH) assays, and hence suppression or elevation of TSH has been regarded as a sufficient criterion for the diagnosis of thyroid dysfunction in conjunction with measurements of free thyroid hormones. ${ }^{1}$

In the late 1990s it was recognized that depressed subjects with a normal serum TSH could have an exaggerated response to TRH stimulation. For the first time it was suggested that this could be evidence of a very mild degree of subclinical hypothyroidism that could not be diagnosed reliably with screening TSH alone. ${ }^{2}$ In 1999, it was again suggested that hypothyroidism is an ongoing disease state starting with only a positive TRH test followed by TSH elevations and progressing to overt hypothyroidism and thyroid hormone failure. Indeed, these authors coined the term sub-biochemical hypothyroidism to denote this earliest phase of primary hypothyroidism in which serum free T4 and TSH levels are still within the reference range but the TRH response is exaggerated similar to established primary hypothyroidism. ${ }^{3}$ Finally, in 2005 , these observations were extended to pediatric subjects. ${ }^{4}$ Again the authors concluded that if there is a goiter and serum TSH is in the upper half of the normal range, a TRH test is necessary to exclude hypothyroidism since basal TSH might not be enough to diagnose this earliest phase of subclinical hypothyroidism. We thus decided to look into a similar group of subjects with normal baseline TSH to see if these findings were reproducible in our population of patients.

We retrieved records of TRH testing from our radioimmunoassay lab computer database that was performed between 2001 and 2005. Patients were referred to our dynamic testing facility for a TRH test if there was a strong suspicion of hypothyroidism, despite a normal basal TSH (either low [suggestive of central hypothyroidism] or low-normal free T4 [FT4] with suggestive clinical features). The patients were then followed in the endocrinology clinic, and those patients with an exaggerated response to TRH were considered, based on the individual merits of the case, for therapy along the lines of primary hypothyroidism. We did not evaluate response to therapy, but no patient started 
on thyroxine (initial dose $25 \mu \mathrm{g}$ ) subsequently had a suppressed TSH. Female patients were not referred for testing if they were pregnant or taking oral contraceptives. We obtained patient serum samples at 0,20 , and 60 minutes after intravenous $200 \mu \mathrm{g}$ TRH (Protirelin) administration. Each serum sample was separated and then preserved at $-20^{\circ} \mathrm{C}$ in the laboratory until analysis. Serum TSH concentration was determined by an immunoradiometric assay (IRMA) (DPC, Inc., Los Angeles, CA) coat-a-count kit with a sensitivity of $0.03 \mathrm{mU} / \mathrm{L}$ and coefficient of variation (intra-run and inter-run) of under $10 \%$. FT4 and free T3 (FT3) were analyzed by the AMERLEX-MAB* FT4, FT3 kits (Trinity Biotech plc, Ireland) which utilize a direct, labeled antibody, competitive radioimmunoassay technique. The reference ranges in our laboratory are as follows: TSH $(0.27$ to 4.8 $\mathrm{mIU} / \mathrm{L}$ ), FT3 (3.3 to $7.2 \mathrm{pmol} / \mathrm{L}$ ), and FT4 (11.0 to 24.0 $\mathrm{pmol} / \mathrm{L})$.

The fold-TSH (defined as 20-minute TSH divided by basal $\mathrm{TSH}$ ) and the $\Delta \mathrm{TSH}$ (defined as 20 -minute TSH minus basal TSH) were calculated after the TRH test. The fold-response was considered an additional variable because of its linear relationship to basal TSH, which was not the case with $\Delta \mathrm{TSH}$. To define an exaggerated or blunted response, we looked at previous studies that have evaluated the operating characteristics of the TRH test in normal humans. These studies demonstrated a minimum peak TSH, following the TRH test, to be $5 \mathrm{mU} / \mathrm{L}$ while the maximum ranged between 17.2 to $19.5 \mathrm{mU} / \mathrm{L} .5,6$ The mean peak TRH response was 9.6 $\pm 0.4 \mathrm{mU} / \mathrm{L} .{ }^{1}$ The mean $\Delta \mathrm{TSH}$, which is expected to be lower than the peak TSH values, has also been reported to be 7.9 to $9.9 \mathrm{mU} / \mathrm{L} \pm 4.5$ to $6.8 \mathrm{mU} / \mathrm{L}$ in normal subjects, ${ }^{7-9}$ while no euthyroid controls had a $\Delta \mathrm{TSH}<7 \mathrm{mU} / \mathrm{L}$ or $>25 \mathrm{mU} / \mathrm{L} .{ }^{10} \mathrm{~A}$ $\Delta \mathrm{TSH}$ value of $<7 \mathrm{mU} / \mathrm{L}$ is also widely considered the threshold for a blunted TRH response. ${ }^{7}$ We therefore define a $\Delta \mathrm{TSH}$ below $7 \mathrm{mU} / \mathrm{L}$ as being blunted while a $\Delta \mathrm{TSH}<20$ to $25 \mathrm{mU} / \mathrm{L}$ as being a normal response. All patients with a $\Delta \mathrm{TSH}<7 \mathrm{mU} / \mathrm{L}$ were excluded, and thus, results from 66 subjects were available for analysis.

The basal TSH concentrations had a median of $2.2 \mathrm{mU} / \mathrm{L}$, interquartile range 1.6 to $3.3 \mathrm{mU} / \mathrm{L}$, and range 0.5 to 4.8 $\mathrm{mU} / \mathrm{L}$. The $\Delta \mathrm{TSH}$ in those without an exaggerated TRH response correlated weakly, but positively with basal TSH $(\mathrm{r}=0.33, P=0.02)$. However, a good linear but inverse relationship between the TSH fold-response $(20 \mathrm{~min}$ $\mathrm{TSH} / \mathrm{basal} \mathrm{TSH}$ ) and basal TSH was seen in this group (figure 1A). As can be seen in figure $1 \mathrm{~A}$, at a threshold $\Delta \mathrm{TSH}$ of 20 $\mathrm{mU} / \mathrm{L}$ there were two distinct populations of subjects where the fold responses were clearly different. Both groups, however, showed a good linear relationship of the fold response with basal TSH in the range of 1 to $5 \mathrm{mU} / \mathrm{L}$ of basal $\mathrm{TSH}$. Also, from figure 1A it is evident that at a basal TSH below $1 \mathrm{mU} / \mathrm{L}$ there is a false increase in the fold response due to a low TSH that is not reflected by an increased $\triangle \mathrm{TSH}$. The latter is a reflection of the fact that lower basal TSH values would lead to an exaggeration of the fold response
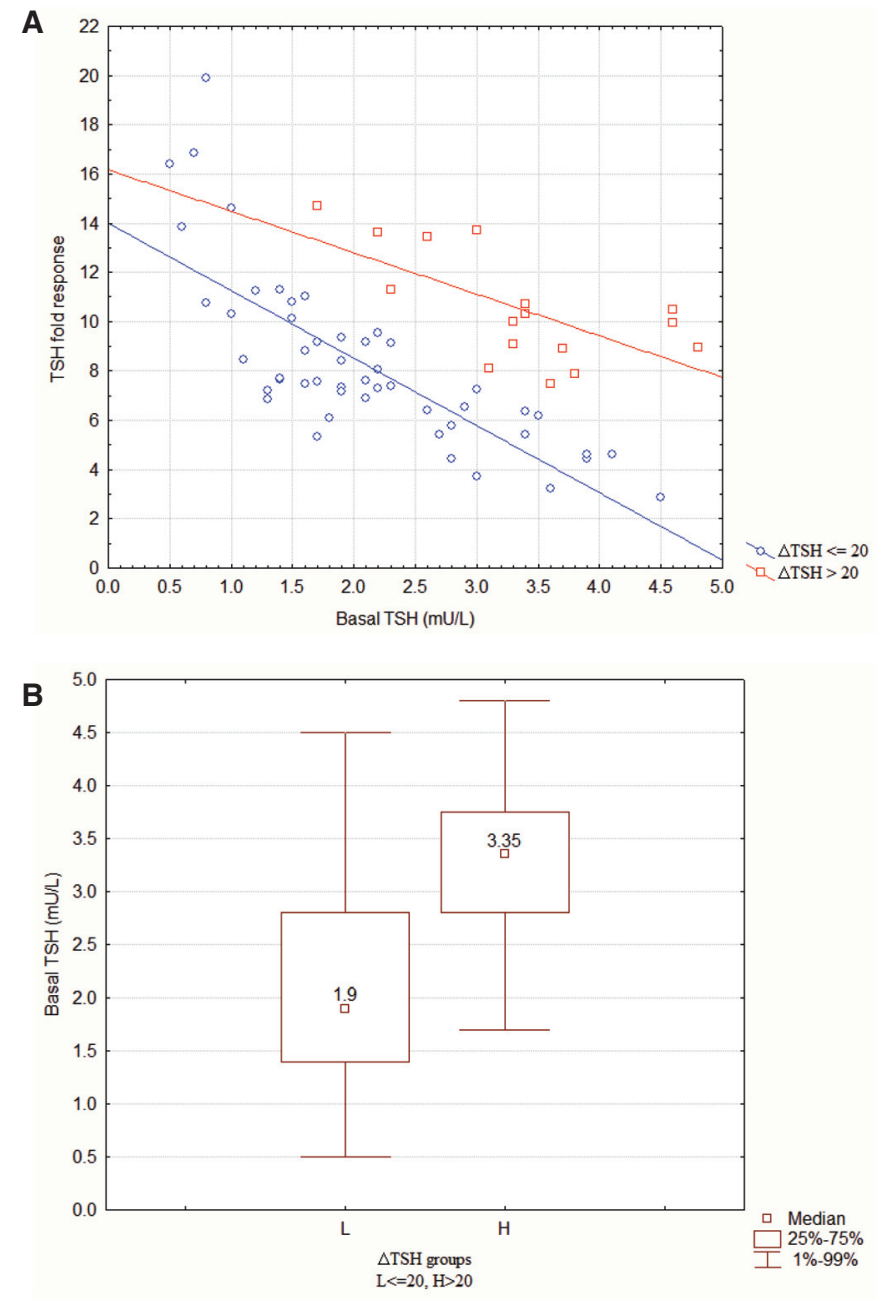

Figure 1. (A) Categorized scatterplots of basal TSH versus $\mathrm{TSH}$-fold response grouped by $\Delta \mathrm{TSH}$ groups. (B) Categorized boxplots of basal TSH grouped by the $\triangle \mathrm{TSH}$ groups

simply because of the mathematical effect of a TSH $<1$, rather than reflect true increases in $\Delta \mathrm{TSH}$. Also, most of the truly exaggerated TRH responses occurred above a basal TSH of about $2.5 \mathrm{mU} / \mathrm{L}$ (figure 1B). FT3 and FT4 levels were similar in both $\Delta$ TSH groups (t-test, $P>0.05$ ), albeit low-normal for FT4 (mean $\pm \mathrm{SD}$, pmol/L): FT4: $12.2 \pm 3.7$ versus $10.8 \pm 1.6$, FT3: $4.5 \pm 0.8$ versus $4.5 \pm 0.5$.

These data suggest that indeed a $\Delta \mathrm{TSH}>20 \mathrm{mU} / \mathrm{L}$ in response to TRH stimulation may be due to early primary hypothyroidism, which may indeed be termed "sub-biochemical" (a term originally coined by Sheth et $\mathrm{al}^{3}$ in 1999) since basal biochemistry is normal. This state is most likely in subjects with a basal TSH $>2.5 \mathrm{mU} / \mathrm{L}$ as previously suggested by Evliyaoglu et $\mathrm{al}^{4}$ and resembles biochemically central hypothyroidism, but can clearly be distinguished by a TRH test. Finally, others have suggested that a $\Delta$ TSH cutoff of 25 to $30 \mathrm{mU} / \mathrm{L}$ or a 6 -fold rise in TSH at 20 minutes are the cutoffs that suggest hypothyroidism. ${ }^{4,11}$ We used a more intuitive method to arrive at our estimated cutoff of $20 \mathrm{mU} / \mathrm{L}$ and suggest this as more optimal. We do not advocate the fold-response as it varies with the basal TSH. 
The utility of identifying these patients lies in the recent increase in the amount of evidence supporting the treatment of patients with subclinical hypothyroidism. This approach is supported by many studies demonstrating an association between subclinical hypothyroidism and adverse health outcomes. In a meta-analysis, subclinical hypothyroidism was associated with a significant risk for coronary heart disease at baseline and after a period of follow-up of between 4 and 20 years with relative risks of 1.53 and 1.18 , respectively. ${ }^{12}$ In angina patients who underwent coronary catheterization, those with a TSH level of 2.1 or higher were more likely to have multiple vessel disease than patients with a lower TSH. ${ }^{13}$ Subclinical hypothyroidism has also been reported to be associated with congestive heart failure in a prospective study of 2730 elderly men and women aged 70 to 79 years followed for 4 years. ${ }^{14}$ Subclinical hypothyroidism was associated with increased risk of congestive heart failure among older adults with a TSH level of 7 or higher. Although these observational studies and others ${ }^{15}$ have shown the presence of an association between subclinical hypothyroidism and heart disease, the question still remains whether treating these patients will reduce the risk of coronary heart disease. Several studies suggest a benefit since subclinical hypothyroidism is also associated with many coronary heart disease risk factors, most importantly dyslipidemia. In a randomized, double blind crossover study of 100 patients with subclinical hypothyroidism, treatment with levo-thyroxine resulted in a significant reduction in serum cholesterol and low-density lipoprotein-cholesterol (LDL-C). ${ }^{16}$ Treatment was also associated with improved endothelial function. In a population-based study, serum total cholesterol and LDL-C levels were significantly higher in patients with subclinical hypothyroidism compared to euthyroid patients. ${ }^{17}$ Treatment of such subclinical hypothyroidism patients with dyslipidemia results in a significant reduction in total cholesterol and LDL-C levels in those whose TSH levels were between 0.2 to $2.0 \mathrm{mIU} / \mathrm{L} .{ }^{18}$ Treatment of subclinical hypothyroidism also results in improved right ventricular systolic and diastolic function among patients with existing abnormalities. ${ }^{19}$

In summary, we document that an exaggerated TRH response indeed occurs in many subjects with a normal biochemistry, the giveaway being a high-normal TSH and a low-normal or even low FT4. We also suggest that the notion of an early "sub-biochemical" state of hypothyroidism may be plausible and needs further study. Even though the TRH test is seldom used in clinical practice at present, a larger prospective study is in order. Until then, physicians may once again need access to TRH for diagnostic use.

\section{References}

1. Spencer CA, Schwarzbein D, Guttler RB, LoPresti JS, Nicoloff JT. Thyrotropin (TSH)-releasing hormone stimulation test responses employing third and fourth generation TSH assays. J Clin Endocrinol Metab 1993;76:494-498.
2. Kraus RP, Phoenix E, Edmonds MW, Nicholson IR, Chandarana PC, Tokmakejian S. Exaggerated TSH responses to TRH in depressed patients with "normal" baseline TSH. J Clin Psychiatry 1997;58:266-270.

3. Sheth JJ, Thakore PB, Trivedi BB, Shah NN, Vaidya RA. Sub-biochemical hypothyroidism: an exaggerated thyroid stimulating hormone response to thyrotrophin releasing hormone. J Assoc Physicians India 1999;47:275-279.

4. Evliyaoglu O, Berberoglu M, Ocal G, Adiyaman P, Aycan Z. Exaggerated TSH responses to TRH in patients with goiter and 'normal' basal TSH levels. Horm Res 2005;64:299-302.

5. Sawin CT, Hershman JM. The TSH response to thyrotropinreleasing hormone (TRH) in young adult men: intraindividual variation and relation to basal serum TSH and thyroid hormones. J Clin Endocrinol Metab 1976;42:809816.

6. Saberi M, Utiger RD. Augmentation of thyrotropin responses to thyrotropin-releasing hormone following small decreases in serum thyroid hormone concentrations. J Clin Endocrinol Metab 1975;40:435-441.

7. Garbutt JC, Mayo JP Jr, Mason GA, Quade D, Loosen PT, Prange AJ Jr. Interpretation of the thyrotropin (TSH) response to thyrotropin-releasing hormone (TRH): implications of an improved TSH assay system. Biol Psychiatry 1991;29:718-720.

8. Tukel R, Kora K, Hekim N, Oguz H, Alagol F. Thyrotropin stimulating hormone response to thyrotropin releasing hormone in patients with panic disorder. Psychoneuroendocrinology 1999;24:155-160.

9. Loosen PT, Mason GA, Prange AJ Jr. The TRH test in normal subjects: methodological considerations. Psychoneuroendocrinology 1982;7:147-153.

10. Bunevicius R, Lasas L, Kazanavicius G, Prange AJ Jr. Pituitary responses to thyrotropin releasing hormone stimulation in depressed women with thyroid gland disorders. Psychoneuroendocrinology 1996;21:631-639.

11. Mojiminiyi OA, Rege V, Bolodeoku J, Wilcox AH, Barron JL. Thyroid autoantibodies and the response to thyrotropin releasing hormone in patients with subclinical hypothyroidism. J Clin Pathol 1995;48:463-465.

12. Singh S, Duggal J, Molnar J, Maldonado F, Barsano CP, Arora R. Impact of subclinical thyroid disorders on coronary heart disease, cardiovascular and all-cause mortality: A metaanalysis. Int J Cardiol 2007 Apr 13; [Epub ahead of print].

13. Yun KH, Jeong MH, Oh SK, Lee EM, Lee J, Rhee SJ, Yoo NJ, Kim NH, Ahn YK, Jeong JW. Relationship of thyroid stimulating hormone with coronary atherosclerosis in angina patients. Int J Cardiol 2007 Jan 11;[Epub ahead of print].

14. Rodondi N, Newman AB, Vittinghoff E, de Rekeneire N, Satterfield S, Harris TB, Bauer DC. Subclinical hypothyroidism and the risk of heart failure, other cardiovascular events, and death. Arch Intern Med 2005; 165:2460-2466.

15. Rodondi N, Aujesky D, Vittinghoff E, Cornuz J, Bauer DC. Subclinical hypothyroidism and the risk of coronary heart disease: a meta-analysis. Am J Med 2006;119:541-551.

16. Razvi S, Ingoe L, Keeka G, Oates C, McMillan C, Weaver JU. The beneficial effect of L-thyroxine on cardiovascular risk factors, endothelial function and quality of life in subclinical hypothyroidism: randomised, crossover trial. J Clin Endocrinol Metab 2007;92:1715-1723. Epub 2007 Feb 13.

17. Walsh JP, Bremner AP, Bulsara MK, O'leary P, Leedman PJ, Feddema P, Michelangeli V. Thyroid dysfunction and serum lipids: a community-based study. Clin Endocrinol (Oxf) 2005;63:670-675. 
18. Iqbal A, Jorde R, Figenschau Y. Serum lipid levels in relation to serum thyroid-stimulating hormone and the effect of thyroxine treatment on serum lipid levels in subjects with subclinical hypothyroidism: the Tromso Study. J Intern Med 2006;260:53-61.

19. Turhan S, Tulunay C, Ozduman Cin M, Gursoy A, Kilickap M, Dincer I, Candemir B, Gullu S, Erol C. Effects of thyroxine therapy on right ventricular systolic and diastolic function in patients with subclinical hypothyroidism: a study by pulsed wave tissue Doppler imaging. J Clin Endocrinol Metab 2006;91:3490-3493.

\section{Author Affiliations}

Suhail A.R. Doi, PhD, FRCP

Department of Medicine (Endocrinology)

Mubarak Al-Kabeer Teaching Hospital and

Kuwait University, Kuwait

Daisy Issac, MSc

Radioimmunoassay Laboratory

Mubarak Al-Kabeer Teaching Hospital

Jabriya, Kuwait

Sheikha Abalkhail, MRCP

Department of Medicine (Endocrinology)

Mubarak Al-Kabeer Teaching Hospital

Jabriya, Kuwait

Marwa M. Al-Qudhaiby, MBBS

Department of Medicine (Endocrinology)

Mubarak Al-Kabeer Teaching Hospital

Jabriya, Kuwait

Mohamad F. Hafez, MBBS

Department of Medicine (Endocrinology)

Mubarak Al-Kabeer Teaching Hospital

Jabriya, Kuwait

Kamal A. S. Al-Shoumer, PhD, FRCP

Department of Medicine (Endocrinology)

Mubarak Al-Kabeer Teaching Hospital and

Kuwait University, Kuwait 